logos_i_ethos_2020_special issue, pp. 159-188

DOI: http://dx.doi.org/10.15633/lie.3772

Sebastian Gałecki

Katarzyna Szufa

https://orcid.org/0000-0003-2728-0447

https://orcid.org/0000-0002-6973-0920

\title{
The contemporary science and the new theo(cosmo)logy project
}

In the history of theology we encounter several stages of the relation between religious thought and exact science data. A particularly negative example has been the one of physico-theology model, i.e. a theological approach which in science seeks only confirmation of its own theses and views. Unfortunately, this paradigm is not to be found in history books only it is still a living paradigm frequently included in lectures and writings by contemporary theologians. Several dozen years ago a new project was originated; it was popularised by two Polish clergymen - John Paul II and Michał Heller. It is often referred to as "new theology." Underlying this project is a change in the attitude to scientific data: science is not to be searched for corroboration of theological theses, but rather inspiration for creative consideration of not only the contents of the Revelation, but also traditional Christian views, theories and doctrines.

"New theo(cosmo)logy," which is proposed and briefly discussed in the present paper, is supposed to fulfil the postulate of a "new theology" 
in the sphere of cosmological questions - hence the infix "cosmo." The following sketch focuses on three issues. Firstly, we outline what physicotheology was (and is), pointing to its major shortcomings and errors. Secondly, we introduce the reader to the main assumptions behind the paradigm of "new theology." Lastly, we try to show how this postulated approach may be realised in the borderland between theology and cosmology: we make use of four example topics in which contemporary physics and the Christian doctrine converge.

\section{Science confirming a theology}

For several dozen years the term "god of the gaps" has been tremendously popular. It is of course critical in character: God treated as a hypothesis explicating the existing gaps and limitations in current scientific understanding. ${ }^{1}$ Since the times of Dietrich Bonhoeffer and Charles A. Coulson, philosophers and scientists have been using this term to (with some measure of irony) distance themselves from such a manner of understanding theology in which any gaps in the current scientific knowledge - whether in physics, cosmology, biology, or any other field of scientia - are treated as proofs of the existence of the transcendent Absolute.

The term "god of the gaps" was not invented as a rhetorical device to testify to the thinker's eloquence. It is a response to the popular and influential theories developed in the fields of theology and philosophy of religion, which boast a tradition of twenty-five centuries, and which have their origins in the classical Greek concept of God as the efficient cause (causa efficiens) of the Universe, which in the Middle Ages came to be most fully expressed in Saint Thomas Aquinas' "fifth way." Until roughly the 17 th century this idea was merely a philosophical and theological

1 See E. Simmons, God of the gaps, [in:] Encyclopedia of science and religion, ed. J. W. von Huyssteen, New York 2003, p. 382.

2 See St. Thomas Aquinas, Summa Theologiae, pars I, q. 2, a. 3, English edition: idem, The "Summa Theologica", trans. Fathers of the English Dominican Province, vol. 1, London 1920, p. 26-27. 
theory. It was only the Enlightenment, along with its discoveries and the extraordinary development of life sciences, that as if "absorbed" the teleological argument into the area of interest of the nascent modern physics, biology and other branches of knowledge. In the history of ideas this amalgam is called "physico-theology."

"In the seventeenth and eighteenth centuries, however, when modern science was becoming established - writes David R. Oldroyd - there was a distinctive genre of texts generally referred to as «theories of the earth». These writings sought to interweave science and theology in what was then called "physico-theology». They sought to provide a scientific basis for theological ideas and to make religion acceptable to reason as well as to faith." ${ }^{3}$ Now we know where to look for the origins of physico-theology - in the scientific revolution above all connected with the Newtonian revolution. We also know the reason for the popularity of this concept: it was used to "scientify" (in the modern sense of the word) Christian theology and worldview. The dramatically increasing authority of life sciences was an enticing incentive to use it to amplify the religious message, seeking "to prove the existence and attributes of God from the evidence of purpose and design in the physical universe." The theological order ("the existence and attributes of God") was to be as certain as the empirical order. Purposiveness, so far captured in philosophical terms ( $\tau \eta \lambda$ oc, finis) was to be identified with causality observable in the material world.

However, anyone regarding this position as a thing of the past would be mistaken. As mentioned before, physico-theology is a predecessor of the idea that has in our times been termed god of the gaps. It is a remarkable fact that more or less at the same time when the book entitled Science and Christian Belief included this term (the first half of the 1950s), in an address to scientists Pope Pius XII stated that "contrary

3 D. R. Oldroyd, Theories of the earth and its age before Darwin, [in:] History of science and religion in western tradition: an encyclopedia, ed. G. B. Ferngren, New York-London 2000, p. 446.

4 M. H. Carré, Physicotheology, [in:] Encyclopedia of philosophy, ed. D. M. Borchert, vol. 7, Detroit 2006, p. 556. 
to rash statements in the past, the more true science advances, the more it discovers God, almost as though He were standing, vigilant and waiting, behind every door which science opens," thanks to which "by means of exact and detailed investigations into the macrocosm and the microcosm, [we have] widened and deepened to a considerable extent the empirical foundation upon which the argument is based and from which we conclude a self-existent Absolute [ens a se] immutable by nature." The physico-theological mentality has, therefore, remained present till this day, with some support from certain ecclesiastical positions, and the so-called intelligent design being its most distinct manifestation over the recent years.

It is no wonder, then, that the god of the gaps attitude has its opponents not only among scientist-critics of religion as such (Richard Dawkins, Daniel Dennett to name but a few), but among Christian theologians as well. Their negative evaluation of this concept has been best captured by Włodzimierz Skoczny, who comments on Pius XII’s above-quoted address thus: "As he refers to the achievements of contemporary science (mentioning the age of the universe, evolution of the cosmos, geological research), the Pope sees them as confirmation of the Christian vision of the world. [...] This address contains all the characteristic features of physico-theology, and so the turn towards sciences is only motivated by apologetics; a selection is made of scientific data (the theory of evolution gets no mention, but the Big Bang theory is emphasised), the role of which is reduced to proving theological propositions." 6 Given the above, manipulation of facts, a selective use of scientific achievements, treatment of science as subordinate to theology and the theistic worldview are all "deadly sins" of physico-theology. Is Skoczny's opinion not a trifle too harsh or unfairly one-sided?

5 Pius XII, Le prove della esistenza di Dio alla luce della scienza naturale moderna, "Acta Apostolice Sedis" 44 (1952), p. 31 and 42.

6 W. Skoczny, Dziedzictwo fizykoteologii we współczesnej myśli chrześcijańskiej, “Zagadnienia Filozoficzne w Nauce" 13 (1991), p. 84. 
One of the first Christian critics of physico-theology was John Henry Newman, who later was appointed cardinal and lately canonised. The bulk of his three presidential lectures addressed the Catholic University of Ireland treated of this subject. Interestingly enough, the objections raised by Newman to physico-theology coincide almost entirely with Skoczny's opinion. As he regards possible bearing of theology on the development of other branches of knowledge, Newman says: so-called "Physical Theology is a most jejune study, considered as a science, and really is no science at all, for it is ordinarily nothing more than a series of pious or polemical remarks upon the physical world viewed religiously." Quite a noteworthy thing: a Catholic thinker criticises physico-theology for not falling within the definition of science, and being only "a most jejune study" and "pious remarks"!

In A Lecture in the School of Medicine Newman points to another fundamental problem: "There are a great many minds so constituted that, when they turn their thoughts to the question of the existence of a Supreme Being, they feel a comfort in resting the proof mainly or solely on the Argument of Design which the Universe furnishes. [...] Physical Theology, then, is pretty much what it was two thousand years ago, and has not received much help from modern science: but now, on the contrary, I think it has received from it a positive disadvantage, I mean, it has been taken out of its place, has been put too prominently forward, and thereby has almost been used as an instrument against Christianity." ${ }^{8}$ What we are dealing with here is again an objection to the instrumental use of science, which is supposed to provide Christians with the "comfort" of validation of the teleological argument. This manner of rationalisation of religion brings more harm than good, becoming "an instrument against Christianity."

7 J. H. Newman, Bearing of Theology on Other Branches of Knowledge, [in:] idem, The Idea of a University, London 1907, p. 61.

8 J. H. Newman, Christianity and Physical Science, [in:] idem, The Idea of a University, op. cit., pp. $450-451$. 
The same problem is pointed out by Michał Heller, who notes that the physico-theological theory can be associated with two major errors: a theological one and a methodological one. "The theological error was pointed out to Newton by Leibniz, who wrote that the Newtonian God did not have enough foresight to create a perfect work that would not need any improvements. The methodological error soon came to the fore, when the development of science gradually filled the gaps in the previous theories, thereby making "the hypothesis of God» redundant." This methodological oversight may really become (to use Newman's wording) an instrument against Christianity. The reason for this seems to be obvious. The gaps in the life sciences of the 17th and 18th centuries were gradually filled by the developments in the subsequent decades, so that the "God," artificially crammed in them, was removed - the process continued until the famous conversation between Napoleon and Laplace, when in answer to a question about God's place in his system, marquis de Laplace replied: "Your Excellency, I have no need of this hypothesis." ${ }^{10}$ Since the times of the co-creator of the theory of probabilities, science has also made considerable progress, which means that God as a hypothesis explicating gaps in knowledge has become redundant in subsequent scientific theories and disciplines.

As regards the "theological error" mentioned by Heller, it gives rise to metaphysical problems: the universe that necessitates God's direct intervention ("filling of gaps" in nature) proves the imperfection of the Design, and by extension: of the Designer.

Lately, Balázs Mezei, a Hungarian philosopher specialising in, inter alia, the idea of religion and Revelation, has spoken out most fiercely against the attitude that closely binds Christian theology and philosophy with the classical cosmological concept. In his paper he calls for "demythologisation of Christian philosophy," which is to take place

9 M. Heller, Ostateczne wyjaśnienia wszechświata, Kraków 2008, p. 190.

10 See J. C. Polkinghorne, One World. The Interaction of Science and Theology, PhiladelphiaLondon 2007, p. 7. 
by way of rejecting cosmotheology. ${ }^{11}$ This concept seems to encapsulate a somewhat narrower view of physico-theology, which is associated not so much with the scientific accomplishments of the Enlightenment as with the classical image of the world as developed in antiquity and the Middle Ages. "The pre-Copernican view of the universe - writes Mezei - offered an understanding of the cosmos as an organic unity in which human beings possess a central place [...]. This universal understanding indeed permeates the whole attitude, general features and particular views of these authors so that no important part of these philosophies can be understood without taking into account the pre-Copernican view. I emphasize that this view is not merely «astronomical» in our sense today, but rather an overarching mystical perspective in which the origin and end of human beings, the meaning of the universe itself, the role of history, societies, and the sciences are conceived as forming a meaningful whole." ${ }^{12}$ The Hungarian thinker points to an even more significant problem concerned with physico-theology (or cosmotheology): the blending of perspectives - physical, biological, or cosmological with metaphysical, ethical and theological ones - results in their mutual codependence. Physical theories cease to be understandable outside the context of, say, Thomism, whereas theological concepts use terminology derived from life sciences in the sense that was assigned to them at a specific historical moment, without regard for the changes that naturally take place in relation to the designata of the terms as knowledge expands.

There is no denying that "in Christianity, the presence of cosmotheology is evident in many writings, symbols, and cultural phenomena,"

11 The concept of cosmotheology seems to have been introduced by Immanuel Kant - it appears in a collection of notes made by a student attending lectures delivered by Kant, entitled Philosophische Abhandlung über Religion und Moral. There, Kant distinguishes between ontotheology and cosmotheology, to which he devotes one paragraph concluded with the following words: "The science of physico-theology is such that we get to know God from the nature or properties of the present world." (see I. Kant, Rozprawa filozoficzna o religii i moralności, trans. K. C. Mrongowiusz, Toruń 2006).

12 B. M. Mezei, Demythologizing Christian philosophy: an outline, "Logos i Ethos" 2013 no. 2 (35), p. 115. 
which more often than not Christian philosophy "uncritically received." This fact makes Balázs Mezei announce the necessity to "demythologise" theological and philosophical language, which is to be understood as a critical history analysis performed with a view to cleansing these disciplines of the unnecessary (in Mezei's opinion) baggage of the ancient and medieval vision of the world. However, his text does not contain any information about the way this demythologised religion is supposed to refer to the current image of the world, which after all somehow affects understanding of the Christian message as well. What is more, the paper under discussion includes some passages that imply the necessity to separate religious consideration from all life science theories. ${ }^{14}$

Is, then, complete cleansing of Christian theology and philosophy of any elements of the scientific image of the world the only solution that will make it possible to avoid the embarrassment to religion? Does the history of physico-theology prove the necessity to constantly cleanse religious and metaphysical concepts of the influence of the current state of cosmology, physics, etc.? Or perhaps Mezei's reaction is too panic-laden and testifies to - to use Heller's wording - "a phobia about binding oneself to any image of the world" evoked by the shock triggered by the necessity to write off the medieval synthesis of science, culture and theology in the wake of the dramatic collapse of the antique vision of the cosmos? ${ }^{15}$ Therefore, the subsequent section of the present paper sets out to answer the following two questions: 1 ) is the relation of religion to science proposed in classical physico-theology (where the science is to provide confirmation for theology) the only possible one?, and 2) is the postulate of cleansing theology of the influence of life sciences possible to fulfil?

13 Ibidem, p. 141.

14 For instance: "The criticism of cosmo-theology, however, is a form of historical criticism. Nevertheless, this criticism points to our insufficient understanding of reality in its entirety and historicity” (ibidem, p. 128). „In the perspective of historical criticism, we cannot consider reality merely in terms of a cosmo-theologically determined objectivity, such as the one we still find in many vistas of our sciences and philosophical reflections today" (ibidem, p. 145).

15 See M. Heller, Naukowy obraz świata a zadanie teologa, [in:] Obrazy świata w teologii i naukach przyrodniczych, ed. M. Heller, S. Budzik and S. Wszołek, Tarnów 1996, p. 15. 


\section{Science inspiring a theology}

Michał Heller, to whom above all we wish to refer in this paragraph, answers these two questions negatively. Let us first address the former one: is it possible to propose a relation between theological sciences and life sciences that is different than the physico-theological one (where findings of life sciences are used only to corroborate and amplify theological propositions)? Heller considers that there is a relation like this - what is more, it is in keeping with both the nature of science as such, and the mentality of the contemporary man: science should not so much confirm theology as inspire it!

Heller's proposal reads thus: "Let us treat the image of the world offered by contemporary sciences «seriously, but not literally». Seriously - i.e. by following the principles of critical realism, which states that in a sense sciences inform us about reality; but not literally - because one needs to realise that sciences idealise and simplify reality, only approximating to it. If this is so, let us ask the following: does the contemporary image of the world not bring some new interpretations («models», as adherents to this direction say) of the traditional religious truths?"16 Let us take a brief look at the elements of the postulate put forward by the Cracow-based philosopher.

Firstly, theology should treat accomplishments by contemporary scientists "seriously, but not literally." Even though it sounds metaphorical, this expression appears to contain the key to understanding his position. Given the previous paragraph, one might venture a thesis whereby the Enlightenment physico-theology treated the then life science knowledge and its findings "not seriously, but literally." As Newman and Skoczny observed: physico-theologians treated science only instrumentally and selectively - such treatment can hardly be recognised as "serious." At the same time, however, due to severe methodological shortcomings, the emergent theories (e.g. the estimated age of the universe, universe expansion, Big Bang, etc.) were by physico-theologians treated literally,

16 M. Heller, Nowa fizyka i nowa teologia, Tarnów 1992, p. 34. 
without due care or critical deliberation. Heller's posulate presupposes that nowadays theologians will be carefully regarding the findings of life sciences, maintaining proper detachment from them, and understanding their methodological status.

Secondly, it is worth noting an interesting dichotomy - even though the author might not have expressed it in a fully intentional manner - between the "contemporary image of the world" and the "traditional truths of faith." Heller does not call for obliterating the difference between the scientific image of the world and religious views (which was the case of physicotheology), but he still believes that the effect of contemporary scientific theories on religion can be invigorating and inspiring, as well as it may help develop a new perspective in describing and understanding theological theses. Contemporaneity and tradition are not mutually exclusive realities, and there should be some creative tension between them.

Interestingly enough, Heller's call for a new approach to the relation between science and theology - which would replace the disgraced physico-theology and the concept of "god of the gaps" - is not an isolated or marginal one. A similar tenor of statement can be found in John Paul II's famous speech on the occasion of the first Castel Gandolfo symposium in 1987. His postulate can be considered to be even more radical: "Contemporary developments in science challenge theology far more deeply than the introduction of Aristotle into Western Europe in the thirteenth century. Yet these developments also offer to theology a potentially important resource. Just as Aristotelian philosophy, through the ministry of such great scholars as St Thomas Aquinas, ultimately came to shape some of the most profound expressions of theological doctrine, so can we not hope that the sciences of today, along with all forms of human knowing, may invigorate and inform those parts of the theological enterprise that bear on the relation of nature, humanity and God?"17 Therefore, the Pope points to invigoration and provision of information as possible fruits of the collaboration between theology and life sciences. What is more, the development of science "challenges"

\footnotetext{
17 John Paul II, Letter to the Reverend George V. Coyne, S.J., Director of the Vatican Observatory, Vatican 1 June 1988.
} 
theology! It provokes reconsideration of traditional religious truths (to use Heller's wording). Tradition does not mean lifelessness, but - as the word's Latin root tradere implies - is about conveying the same truth over and over again.

In Heller's works we can find many examples of this new approach being put into practice: science that inspires and invigorates theology. We have chosen only four of them in order to show, somewhat more practically, what this "new theo(cosmo)logy" may look like.

\section{The Big Bang and the eternal universe}

Let the question about the origin of the world serve as the first example. Contemporary science has been using various ways to answer this question; among the multitude of various cosmological models, the current paradigm is the Big Bang model, which is based on Albert Einstein's general theory of relativity.

According to the Big Bang theory the universe came into existence around 13.7 billion years ago as a result of a gigantic explosion of infinitely dense and hot point (the so-called initial singularity). Ever since the universe has been continually expanding: the density is decreasing and the mean temperature is falling. With the benefit of the laws of physics known today, we can reconstruct the history of the universe, going back as far $10^{-43}$ seconds (the so-called Planck time). Many predictions based on the Big Bang theory have been confirmed experimentally. One of the most important achievements was the discovery and description of the microwave background radiation, which is a remnant of the reactions taking place in the early universe, when the temperature was $3000^{\circ} \mathrm{K}$. Under those conditions ever-present photons did not have enough energy to react with matter particles (to ionise hydrogen and helium atoms) and began scattering freely throughout space. ${ }^{18}$

Despite the successes of the standard cosmological model, it cannot be used to describe the universe in the Planck era, that is as of the "zero

18 See G. F. Smoot III, Cosmic Microwave Background Radiation Anisotropies: Their Discovery and Utilization, "Review of Modern Physics" 79 (2007), pp. 1349-1350. 
moment" to $10^{-43}$ seconds after the Big Bang. For this purpose we need a completely new theory that would encompass all interactions in the world: gravitational, electro-magnetic, weak nuclear and strong nuclear, including quantum effects of gravity - it is popularly referred to as the "theory of everything." James Hartle and Steven Hawking undertook this task, constructing their model of the beginning of the universe, which combines the general theory of relativity with quantum mechanics, and developing a hypothesis of the world that needs no boundary conditions. The author of A Brief History of Time summarises his views in the conclusion of the book as follows: "When we combine quantum mechanics with general relativity, there seems to be a new possibility that did not arise before: that space and time together might form a finite, four-dimensional space without singularities or boundaries, like the surface of the earth." ${ }^{19}$ Also, Hawking says that the concept of time has no meaning before the beginning of the universe, and the choice between imaginary time (obtained by multiplying the time coordinate by an imaginary unit, i.e. a square root of -1) and real time is only a matter of descriptive convenience.

Heller takes these data "seriously, but not literally." The thing that a philosopher of nature and theologian might find particularly interesting is the issue of temporality: "many contemporary propositions and models of the very early Universe describe the Planck era as a temporal and a spatial. In this sense, the most radical suggestion is constituted by [...] the noncommutative model, where all local concepts are excluded by the very nature of noncommutative geometry." ${ }^{20}$ Interestingly enough, the history of Christian theology offers a very interesting concept advocated above all by Saint Thomas Aquinas, ${ }^{21}$ which propounds a possibility of the eternal existence of the world (which would not be contrary to the revealed truth about the world being created by God). This theory had

\footnotetext{
19 S. W. Hawking, A Brief History of Time, , New York 1988, p. 173.

20 M. Heller, Filozofia i wszechświat. Wybór pism, Kraków 2006, p. 469.

21 See Thomas Aquinas, On the Eternity of the World, [in:] idem, Selected Writings, ed. \& transl. R. McInerny, London 1998, pp. 711-717.
} 
a lot of opponents and in the end remained merely a medieval theological hypothesis.

With the benefit of the latest discoveries - which are often mentioned by Hawking - it appears that "a contemporary theologian should take into account the possibility of returning to the traditional doctrine of the creation of the Universe as an atemporal (and aspatial) act." ${ }^{22}$ Heller points out at least two premises indicating this direction of research. Firstly, Aquinas' doctrine distinguishes the creation of the world from the beginning of the world: the creation is a theological, metaphysical truth which determines a cause-effect relationship (God is the cause of the existence of the universe). Establishing the beginning of the world belongs in the order of natural sciences.

Therefore, if scientists, equipped with the latest research results, seem to treat the beginning of the universe as an atemporal phenomenon, then theologians should also consider recognising the act of creation as an atemporal process. "If we regard the original singularity as a physical equivalent of the theological concept of the beginning of the universe - writes Heller - then we are bound to find that from the perspective of the macroscopic observer, the Universe had its beginning a finite number of years ago, but from the perspective of the fundamental level of theory [...] the very concept of the beginning is meaningless. ${ }^{23}$ Hence, it appears that close to one thousand years after Saint Thomas Aquinas substantiated the non-contradiction of the concept of the eternal universe and the Christian Revelation, natural sciences point to further and very interesting implications of Aquinas' hypothesis. Given the development of the (cosmological and physical) concept of the atemporal beginning of the universe, where the establishment of the beginning is impossible ("a lack of edge in space and time"), it is worth returning to the theological thesis whereby "although created, the Universe has existed since temporal minus infinity," and reconsidering it afresh. ${ }^{24}$ 


\section{Fine tuning and the anthropic principle}

The term fine tuning involves associations with precise tuning of musical instruments or a radio receiver. As it appears, it is applicable in natural sciences: it has been found that some constants in the natural world (e.g. the mass of elementary particles) are very finely "tuned" so that the world in which we live can exist. In her cross-sectional paper on cosmological anthropic principles, Sherrilyn Roush poses a question of the degree of this fine tuning (or to what extent the values of the constants in the natural world could change with the world remaining the way we know it). In her opinion, "the answer is dramatic": if we take into consideration the number of finely adjusted factors that are crucial for formation of stable atoms (and by extension: biochemical compounds that life is founded on), the probability of accidental emergence of a world like the one we live in is $1 / 10^{229}$. 25

In the 1930s Paul Dirac pointed out the dimensionless number $\sim 10^{40}$, which often appeared in cosmology, and which we can, for instance, find to be the solution to, inter alia, the following combinations of physical constants:

a quantitative ratio between electromagnetic force and gravitational force in the interaction between an electron and a proton:

$$
\frac{e^{2}}{G m_{p} m_{e}} \approx 10^{40}
$$

a quotient of the radius of the observable universe and the classical electron radius:

$$
\frac{G H^{-1}}{e^{2} m_{e} c^{2}} \approx 10^{40}
$$

25 See S. Roush, Copernicus, Kant, and the anthropic cosmological principles, "Studies in History and Philosophy of Modern Physics" 34 (2003) no. 1, p. 7 and L. Smolin, The life of the cosmos, Oxford 1997, pp. 6-46. 
the number of electrons and protons in the universe:

$$
\frac{p_{0}\left(G H_{0}^{-1}\right)^{3}}{m_{p}} \approx 10^{2 \cdot 40}
$$

Dirac pointed to more relations like this, finding this relationship to be an immutable characteristic of the universe. ${ }^{26}$ Several years later Robert Dicke formulated these coincidences in a somewhat different manner, by making use of the Planck scale (a combination of the constants of nature: speed of light; constants: gravitational, Planck's, Boltzmannexpress basic physical quantities: length, time, mass, temperature) and advancing a hypothesis whereby the constants are of values specified precisely to allow intelligent life on Earth. ${ }^{27}$

During the conference organised in Cracow on the occasion of the 5ooth anniversary of Mikołaj Kopernik birth, Australian physicist Brandon Carter first formulated the anthropic principle (both its strong and weak version), which was underpinned by the above-presented "large number coincidences." Carter strongly believes that "these coincidences should rather be regarded as confirming "conventional» (General Relativistic Big Bang) physics and cosmology which could in principle have been used to predict them all in advance of their observation."28

For many years now, the anthropic principle has been absorbing philosophers' and theologians' minds. Regardless of whether we speak about its "weak" or "strong" version, a peculiar denial of the "Copernican principle," which relegates man to the margin of the universe, must come across as a rather surprising thing. Homo sapiens as a rational "participant observer" appears to be a kind of keystone, as he discovers not only the laws governing the material world, but also something that Heller calls 'Meaning' (with the first letter in upper case): "The cosmic evolution

26 See M. S. Berman, Large number hypothesis, "International Journal of Theoretical Physics" 31 (1992) no. 8, p. 1447; H. Kragh, The origin of the modern anthropic principle, "Journal of Cosmology" 13 (2011), pp. 3702-3703.

27 See H. Kragh, The origin of the modern anthropic principle, op. cit., pp. 3702-3703.

28 B. Carter, Large number coincidences and the anthropic principle in cosmology, [in:] Confrontation of cosmological theories with observational data, ed. M. S. Longair, Dordrecht 1974, p. 291. 
did not spring from metaphysical vacuum and is not headed towards absolute nothingness, but since the beginning it has been suffused with Meaning, even though the Meaning transcends the world of matter and evades analytical methods of science. The anthropic principle arouses us from metaphysical sleep. Man and his existential problems are not an «excrescence» in the Universe. It is not only man that is well adapted to live in the Universe, but the Universe too seems to be strangely adapted to give birth to man and accommodate his problems."29

Let us remember that Heller's presuppositions differ from the ones of physico-theology: by no means can we draw theological conclusions directly from natural science data ("and so science proves the existence of a rational creator"). The so-called fine tuning is to be treated "seriously, but with proper detachment," asking about the ways in which it can enable us to develop or reinterpret traditional religious truths. Certainly, we should take into account the fact that science demonstrates man's evergrowing "coupling" with the surrounding world - and the point is not just that man is heavily dependent on the world in which he lives. Science indirectly proves that the universe too appears to be closely linked with man (as if it could not exist if there were no man in it). "It is astonishing that such severe limitations are imposed by our existence on the structure of the world. [...] Like many of our personal traits are encoded in genes, so was the possibility of our emergence in one way or another intrinsic to the initial conditions of the Cosmos. If we understand the «dust of the ground» as cosmic material, then the biblical metaphor whereby we are made from the «dust of the ground» is much more profound than we have thought before." ${ }^{30}$ In the above quotation Heller makes a reference to the biblical account of the creation of man, in which "the Lord God formed a man from the dust of the ground" (Gen 2:7). In fact, the perspective of a close and mutual interrelationship between man and the surrounding universe enables a more profound interpretation of the words found in the Book of Genesis. 


\section{Quantum revolution and the negative theology}

In 1900, during a session of the German Society of Science, Max Planck proposed a novel explanation of the mechanism of blackbody radioation (back in those days all the theories were drastically irreconcilable with the results of experiments done with regard to short wavelengths - the so-called ultraviolet catastrophe), where he gave up the classical conception of energy as a continuous variable, instead postulating that it be treated as a discrete variable. This meant that energy would be radiated (or absorbed) by a body only in certain portions (an object's energy states would only be characterised by integral, quantised values). The day on which Planck presented his ideas is considered to mark the beginning of quantum mechanics. ${ }^{31}$

The innovations in this new field of physics included a probabilistic approach and the "blurring" of the borderline between the observer and the system under examination. According to the laws of quantum physics, a result of every measurement is a random variable with a specific probability distribution. Before an experiment is done, the system is in a superposition of allowed states (its state is a sum of all possible states). Making a measurement affects the state of the system, which is to be understood that the measurement determines a choice of one of the possibilities. Therefore, if we prepare an arrangement, that is a group of particles in one, specific state, then the result of the measurement for each element in this arrangement may be different. ${ }^{32} \mathrm{~A}$ Schrödinger's thought experiment - the so-called Schrödinger's cat - is a popular illustration of these phenomena.

When contrasted with classical physics, in the microworld quantum mechanics has proved perfect conformity with the experiment. With the benefit of quantum mechanics it was possible to explain phenomena

31 See R. Eisberg, R. Resnick, Quantum Physics of Atoms, Molecules, Solids, Nuclei, and Particles, New York 1985, p. 2.

32 See C. Wetterich, Quantum mechanics from classical statistics, "Annals of Physics" 325 (2010), pp. 860-869. 
taking place at the atomic level, e.g. Albert Einstein was able to explain the photoelectric effect, Arthur Holly Compton was able to describe scattering of photons at quasi-free electrons in the atom. ${ }^{33}$

Even though the question of "quantum revolution" does not seem to be as theologically seminal as the Big Bang theory or fine tuning, many science-religion relationship specialists find it to be a real beginning of a new approach. Ernest Simmons points out that "since about 1990 attention has been devoted to formulating theories where God works in and through the physical systems, such as in quantum indeterminacy, without violating known physical or biological laws. This «causal joint» discussion has resulted in a number of new theories of divine action ranging from top-down or whole-part causation (Arthur Peacocke) to bottom-up (Robert John Russell), Persuasion (John Cobb, David Griffin), Information (John Polkinghorne), or Self-Limitation (W. H. Vanstone), to name a few. What unites these diverse approaches is their commitment to respect the various physical and life sciences in their causal analyses." ${ }^{\prime \prime}$

Though not mentioned by Simmons, Heller too pursues a new theological and philosophical approach to quantum physics. We would like to point to just one example of Hellerian inspiring of theology with scientific discoveries. In a conversation with Giulio Brotti, the Cracowbased philosopher suggests a new understanding of apophatic theology, which is classical in the Christian East (and which is also present in the Latin Church, most often known under the name of negative theology). For it might appear that this is a peculiar regulative and purely theological idea, without any justification in natural sciences. Heller thinks otherwise: "Physics in the 2oth century - and I particularly mean quantum mechanics - tells us that the world of elementary particles is completely different from the macroscopic world in which we live. At the level lower than the so-called Planck length, which is equal to $1.616252 \times 10^{-35} \mathrm{~m}$, the ordinary concepts of time and space seem to be

33 See R. Eisberg, R. Resnick, Quantum Physics of Atoms, Molecules, Solids, Nuclei, and Particles, op. cit., pp. $29-40$.

34 E. Simmons, God of the gaps, op. cit., p. 384. 
devoid of any meaning. This does not, however, mean that the subatomic world is chaotic or irrational. We should rather speak about a much more profound rationality than the one we typically use. Hence, as we posit belief in God, it must be a fortiori acknowledged that He inconceivably transcends our capacity for comprehension." ${ }^{35}$

Let us restate that: Heller does not try to use physical data to prove the existence of God, or His incomprehensibility. He rather attempts to understand the latest theories developed by life disciplines, and ask what their contribution is to the theological understanding of the world. In this case it turns out that, first, incomprehensibility is a fundamental characteristic of the existing universe (even if only at the subatomic level). And second: incomprehensibility does not testify to irrationality, but rather to "much more profound rationality" than the familiar, common type of rationality. This approach is akin to classical negative theology, where God is not irrational, but - for want of a better word - ultrarational. Launching dialogue between theology and quantum mechanics might help develop this thesis.

\section{The second law of thermodynamics, time and mortality}

One of the fundamental laws of thermodynamics is described by the second law of thermodynamics, whereby the function of state describing the level of disorder in an isolated system (i.e. one that does not exchange energy with the surroundings), which is called 'entropy', increases over time. In other words: the processes that take place in such a system cause entropy to increase, thanks to which it is possible to define "the arrow of time" (i.e. the direction in which time flows).

Because in every isolated system production of entropy takes place, the state of a system with low entropy will always precede a state of high

35 M. Heller, Bóg i nauka. Moje dwie drogi do jednego celu, trans. E. Nicewicz-Staszowska, Kraków 2013, pp. 92-93. 
entropy, which in turn will precede one of even higher entropy, etc. A sequence of these events marks a passage of time. ${ }^{36}$

It is noteworthy that an increase in entropy concerns irreversible processes; reversible processes do not involve change (increase) in entropy. However, reversibility in nature is very difficult to effect, because the system needs to undergo a reverse evolution to the initial state, following exactly the same way and passing through exactly the same intermediate states without any energy loss. Hence, entropy of the universe keeps increasing. To put it straight: it is impossible for shards of broken glass to be spontaneously put together to form a glass, much less is it possible to reverse the processes of ageing and death, even at the level of individual cells.

Entropy (S) is defined statistically with the aid of Boltzmann equation: $\mathrm{S}=\mathrm{k} \ln (\mathrm{W})$, where " $\mathrm{k}$ " is Boltzmann constant, and "W" is a number of ways to realise the macroscopic system by microstates. This means that the greater the number of microstates, the more there are possible configurations, and in turn: the higher the entropy. ${ }^{37}$ A probabilistic approach enables a description of complex systems: the concept of entropy is used for, inter alia, modelling of biological systems, e.g. cellular systems. ${ }^{38}$

Death is one of key concepts in both physics, biology and theology. Of course, the heat death of the universe means something different than a biological organism's death, or "the second death" which will not hurt "the one who is victorious" (cf. Rev 2:11). Still, they appear to be analogous concepts. The definition of entropy introduced by physicists might elucidate the Christian perception of evanescence, eternity of God and immortality of the human soul.

In his Confessions, Saint Augustine summarises the Christian tradition concerned with the eternity of God: "Thy years do not come and go; while these years of ours do come and go, in order that they all

36 See D. Halliday, R. Resnick, J. Walker, Fundamentals of Physics, Hoboken 2014, pp. 583-602.

37 See H. A. Martínez-Berumen, G. C. López-Torres, L. Romo-Rojas, Developing a method to evaluate entropy in organizational systems, "Procedia Computer Science" 28 (2014), p. 390.

38 See U. Lucia, Entropy generation approach to cell systems, "Physica A" 406 (2014), p. 1. 
may come. All Thy years stand together, for they stand still, nor are those going away cut off by those coming, for they do not pass away [...]. Thy years are but one day, and Thy day is not a daily recurrent, but today; Thy present day does not give place to tomorrow, nor, indeed, does it take the place of yesterday. Thy present day is eternity" ${ }^{39}$ What makes man and the universe different from God? What is the origin of the difference between the ever-lasting nature of God and the mortality of the created world? This is explained by another traditional Christian truth, which was accurately captured by Thomas Aquinas: "A characteristic of the existence of god is that nothing can be added to it, hence it is distinct from every other existence by its own purity." ${ }^{40}$ Complexity is that which ontologically and specially distinguishes the creation from the creator.

If the process of entropy only applies to complex systems, then God - who should perhaps be modelled as a radically simple system - is not subject to entropy, and so He is not affected by "the arrow of time," evanescence or mortality. Such an approach is also compatible with the Christian faith in the immortality of the soul, which - as a "separate substance" - like angels and demons is immortal as well (even though it is not eternal - it has a distinct beginning; its complexity is greater than that of God, but lesser than that of the material world). The same applies to the actual irreversibility of entropy: in the world as we know it, the arrow of time - according to the current state of knowledge - can point in one direction only, from a more ordered state to a less ordered state.

Heller encourages theology to open up to natural science data also in respect of mortality, evanescence and the concept of eternity. For it transpires that the current image of the world is in line with what fifteen centuries ago Augustine of Hippo wrote. "The unidirectional passing of time is not as absolute as we might believe. Evanescence is a consequence of complexity. The human organism gets old and dies, because it is composed of around five octillion atoms. That which is not

39 Saint Augustine, Confessions, trans. V. J. Bourke, Washington 2008, p. 342-343.

40 Thomas Aquinas, On Being and Essence [in:] idem, Selected Writings, ed. \& transl. R. McInerny, London 1998, p. 45. 
complex does not exist in the flow of time and cannot die. In the light of these deliberations we are coming to better understand the meaning of the saying that death is a passage from time to eternity." ${ }^{41}$ Intuitive or religious separation of that which is eternal from that which is mortal can be described in physical terms. "Evanescence" is a philosophical expression of "entropy," which sounds equally poetical, though belongs to a completely different order of knowledge. Looking for similarities and differences between those two realities may bring about very interesting effects in the form of new theological theses.

\section{Theo(cosmo)logy as realisation of the project of the "new theology"}

There remains the second question to be answered, which implies that perhaps theology needs no inspiration from the current image of the world. Perhaps we should strive to rid, as fully as possible, religious consideration of the influence of life sciences? This is exactly what Heller asks about: "Should theology bind itself to the scientific image of the world?" ${ }^{42}$; the answer to this question can be couched in one sentence: "a theologian always thinks in terms of some image of the world, even if he did not want to." ${ }^{33}$ Therefore, even though the problem concerned with the acceptability of theologians bringing up natural issues is raised frequently, it is ostensible.

Instead, the theological issue of the created world's relationship with its Creator should be raised. Natural sciences deal with an analogous problem, i.e. the origin and evolution of the universe. "It is this image that determines the way theology, in a given era, interprets the truth about the creation of the world by God - note Michał Heller and Tadeusz Pabjan. - Crucially enough, the changeability of the image of the world - caused by, for instance, the development of science - in a way forces

41 M. Heller, Usprawiedliwienie wszechświata, Kraków 1984, p. 62.

42 Idem, Naukowy obraz świata a zadanie teologa, op. cit., pp. 25-27.

43 Ibidem, p. 16. 
theology to continually reinterpret this truth, or at least to supplement the existing interpretation with new elements that will make it consistent with that image." ${ }^{44}$ Theology of creation (like other theological theses) does not operate in a scientific vacuum, but it is strongly conditioned by the current scientific model of the formation and development of the universe. This example best illustrates how crucial is a sound attitude of religious consideration towards scientific postulates.

One can point to at least three reasons why in their research theologians should take account of the current scientific image of the world: ${ }^{45}$

- using some image of the world is unavoidable;

- the requirement that the theological message be intelligible

- the risk of theological theories becoming contrary to wellestablished scientific truths.

Let us take a brief look at this list. Is the use of some image of the world really unavoidable and necessary? For instance, let us consider some concepts crucial for Christianity: "creation of the world," "making man from the dust of the ground," "resurrection," "ascension" or "the end of the world." None of these is neutral, "blind" to natural knowledge: the ascension refers to the concept of heaven and vertical movement; the act of creation always functions in some connection with the process of emergence of the cosmos, etc. Almost all religious truths somehow involve our natural knowledge - that is why everyone (including theologians) perforce thinks "inside" some model of the world. Hence, the question should not be "whether I am using some image of the world," but rather "what sort of image of the world I am using": the current one

44 M. Heller, T. Pabjan, Stworzenie i początek Wszechświata. Teologia - filozofia-kosmologia, Kraków 2013, p. 6.

45 See idem, Naukowy obraz świata a zadanie teologa, op. cit., pp. 25-26; M. Heller, T. Pabjan, Stworzenie i początek Wszechświata, op. cit., pp. 6-7; M. Heller, S. Budzik, S. Wszołek, Nauki jako „locus theologicus” - próba wniosków, [in:] Obrazy świata w teologii i naukach przyrodniczych, op. cit., p. 258. 
well substantiated by science, or an out-dated one which is imprecise or even compromised.

The second reason points to the purpose of theology: to some extent it is a social and practical discipline. The crucial thing for it is contact with an audience - the reader or listener, who more often than not uses (in a more or less conscious way) the current image of the world. If a theologian forms his opinions on the basis of some outdated or erroneous vision of the universe, then the audience will fail to understand or misunderstand it. This kind of risk can be exemplified by the tendency to deal with problems that are irrelevant from the ordinary man's perspective - which is an accusation often made against theologians - as well as to disregard subjects of keen interest to the public opinion.

Thirdly, nowadays formulating theological theses contrary to wellestablished scientific truths exposes theology to ridicule, because the popular perception is that natural disciplines command greater authority. John Henry Newman, who has already been mentioned, invoked in his Idea of a University the presupposition (cardinal maxim) ${ }^{46}$ whereby "truth cannot be contrary to truth," even though "truth often seems contrary to truth." If we choose to abide by this principle, then the conflict between "theological truth" and "scientific truth" must in its essence be ostensible: either due to the falseness of either of the opinions, or due to their logical disjunction. Knowledge of the image of the world formed by the current scientific research enables ongoing confrontation of the results of theological reflection with truths widely recognised in a consensus among naturalists - thanks to which the ostensible conflict can be identified and resolved right from the start.

The dispute between physico-theology and that which might be termed "new theo(cosmo)logy" arises chiefly out of the perception of the mutual relationship between theology and natural sciences. While

46 J. H. Newman, Christianity and scientific investigation, [in:] idem, The idea of a university, op. cit., p. 461. This statement echoes in the 36th section of the Pastoral Constitution on the Church in the Modern World Gaudium et Spes: "if methodical investigation within every branch of learning is carried out in a genuinely scientific manner and in accord with moral norms, it never truly conflicts with faith, for earthly matters and the concerns of faith derive from the same God." 
physico-theology treated science only as an authority saying yes to revealed truths (this goal was often achieved by manipulation and selection of scientific data, passing over inconvenient discoveries, etc.), the new approach sets out to look to scientia for inspiration enabling reconsideration and better expression of some theological theses. The controversy between Pius XII and John Paul II (to use these two figures as personifications of the above attitudes) is perfectly depicted by Ian Barbour in Religion and Science, ${ }^{47}$ where he presents four possible types of relationship between science and religion: conflict, independence, dialogue and integration.

Physico-theology appears to be wishing to realise the fourth model: full integration of natural disciplines and theology. The above-quoted statement of Pius XII reads that science "discovers God, almost as though He were standing, vigilant and waiting, behind every door which science opens," and the growth of natural knowledge results in "gradual discovery of God."

The new approach is much closer to the model of dialogue, which is more about mutual learning and looking for points of contact, certain similarities or analogies, rather than about correlation of conclusions. John Paul II wrote about the challenge, revitalisation and information of religious consideration as possible (and expected!) effects of the relations between theologians and scientists. In scientific achievements Heller looks for inspiration leading to "new interpretations of traditional religious truths." Given the four examples (the eternal universe, the close relation between man and the material world, capacity for cognition of God, and the relation of mortality and eternity) presented in the second part of the present paper, it seems that Heller's presuppositions and goals are not futile. The courage in looking for possible parallels or sources of inspiration must, however, be respectful of the independence of disciplines, and keep a reasonable distance from the scientific image of 1997.

See I. R. Barbour, Religion and science. Historical and contemporary issues, San Francisco 
the world - it was exactly this lack of distance that became the direct cause of the ridicule and collapse of physico-theology.

As he considers the relationship between cosmology and religion, Norriss Hetherington points to a very interesting fact. "Once theology was king of the disciplines - he observes - autonomous, the supreme principle by which all else was understood [...], and producing knowledge of ultimate value. Cosmology was a handmaiden, neither controlling fundamental knowledge nor ways of getting at it, its truths holding a lower logical status and value. The relationship between cosmology and religion is now largely reversed; both religion and politics now direct appeals for legitimacy to science." ${ }^{48}$ This might be viewed as a wicked historical irony, but this fact might as well be approached as a chance. Since the project of physico-theology looking to science for confirmation of theological findings proved to be a grave error, then perhaps we should change our attitude?

The working phrase - "new theo(cosmo)logy" - that we have suggested is a direct reference to one of Heller's statement-making books entitled Nowa fizyka i nowa teologia, where the author writes the following: "The term «new theology» has been in circulation for some time now too. As a matter of fact, contrary to accusations commonly levelled against theology that it is characterised by dogmatism, almost every era had its «new theology». ${ }^{49}$ Sometimes one misrepresentation of the doctrine is enough, or a slight shift in emphasis with regard to traditional teaching for theology to be recognised as 'new', this adjective being construed as an expression of either pejoration or profound recognition. The term «new theology», which features in the title of the present book, was not intended as a reference to this kind of innovation-loving tendency; its overtone is rather to be understood as a postulate." "New theology" is then a research project - or even a new paradigm - in theology, which is supposed to pursue a new methodological approach, dialogue between

48 N. Hetherington, Cosmology, religious and philosophical aspects, [in:] Encyclopedia of science and religion, ed. J. W. von Huyssteen, New York 2003, p. 182.

49 M. Heller, Nowa fizyka i nowa teologia, op. cit., p. 14. 
scientific data on the one hand and the Christian Revelation and Tradition on the other hand.

"New theo(cosmo)logy," as proposed in the present paper, is an attempt at realising the Hellerian postulate in the borderland between theology and cosmology - and so this phrase can be read as "new theology in the face of cosmological data." Its presuppositions fully correspond to the new paradigm, characterised by two words: "inspiration" and "reinterpretation." It acknowledges natural science in the field of cosmology as locus theologicus, a source of new perspective that enables a different view on traditional religious truths. Therefore, it is not a competitive approach in relation to John Paul II's and Michał Heller's projects, but it aspires to become "the second child" in the "new theology" family - next to "the first child," i.e. "theology of science" proposed by Heller: a systematised theological deliberation on the nature of science as such. ${ }^{50}$

In our opinion, next to it (theology of science) there should appear new theo(cosmo)logy: theological reflection not so much on science itself, but religious deliberation on data offered by the current scientific image of the world. The four examples, which are very briefly presented in the second paragraph, can serve as an illustration of how theology can draw inspiration from the theories of natural disciplines in order to make a fresh attempt to understand and describe traditional religious truths. The neologism that we use attempts to encapsulate the following postulate: a kind of "new theology" at the centre of which lies the physical universe, described by contemporary science. Has the time come for "new theo(cosmo)logy"?

50 See, inter alia, ibidem, pp. 116-118 and W. M. Macek, Teologia nauki, [in:] Oblicza racjonalności. Wokół myśli Michała Hellera, ed. B. Brożek et al., Kraków 2011, pp. 203-237. 


\section{Abstract}

\section{The contemporary science and the new theo(cosmo)logy project}

Balázs Mezei, in an essay entitled Demythologizing Christian philosophy: an outline, criticizes the position he describes as "cosmotheology". By this he means a philosophical reflection on the world that is strongly conditioned by the pre-Copernican conception of the universe. In his opinion, the only solution to the problem of "cosmotheology" is to "demythologize" philosophy, freeing it from all cosmological conditions, which constitute only an unnecessary burden. Michał Heller presents a different attitude. He argues that theology - that is, rational reflection on Christian revelation - must take into account what in many publications he calls "the current image of the world." Science is supposed to be a specific locus theologicus: a source of reflection and theological argumentation. A theologian cannot turn his back on such important issues for modern science as the Big Bang theory, the eternity and infinity of the universe, fine tuning of the initial conditions of the universe. These data from the natural sciences can not only inspire but also point to new ways of understanding classical theological theories. It is the concept of "inspiration" that seems to be central to the approach that we have defined as "the new theo (cosmology)". On a few selected examples we want to show how, on the basis of the latest cosmological data, Heller shapes the "new theology", creatively reflecting on questions about the creation of the world, its eternity, and Providence caringly supporting the existence of the universe.

\section{Keywords}

Heller M., Mezei B. M ., Barbour I. R ., god of the gaps, physicotheology, picture of the world, The big bang, fine tuning, the anthropic principle, quantum revolution, negative theology, entropy

\section{Bibliography}

Saint Augustine, Confessions, trans. V. J. Bourke, Washington 2008.

Barbour I. R., Religion and science. Historical and contemporary issues, San Francisco 1997. Berman M. S., Large number hypothesis, "International Journal of Theoretical Physics" 31 (1992) no. 8, pp. 1447-1450. 
Carré M. H., Physicotheology, [in:] Encyclopedia of philosophy, ed. D. M. Borchert, vol. 7, Detroit 2006, pp. 556-563.

Carter B., Large number coincidences and the anthropic principle in cosmology, [in:] Confrontation of cosmological theories with observational data, ed. M. S. Longair, Dordrecht 1974, pp. 291-298.

Eisberg R., Resnick R., Quantum Physics of Atoms, Molecules, Solids, Nuclei, and Particles, New York 1985.

Halliday D., Resnick R., Walker J., Fundamentals of Physics, Hoboken 2014.

Hawking S. W., A Brief History of Time, New York 1988.

Heller M., Bóg i nauka. Moje dwie drogi do jednego celu, trans. E. Nicewicz-Staszowska, Kraków 2013.

Heller M., Budzik S., Wszołek S., Nauki jako „locus theologicus” - próba wniosków, [in:] Obrazy świata w teologii i naukach przyrodniczych, ed. M. Heller, S. Budzik and S. Wszołek, Tarnów 1996, pp. 253-259.

Heller M., Filozofia i wszechświat. Wybór pism, Kraków 2006.

Heller M., Kosmiczna przygoda Człowieka Mądrego, Kraków 1994.

Heller M., Naukowy obraz świata a zadanie teologa, [in:] Obrazy świata w teologii i naukach przyrodniczych, ed. M. Heller, S. Budzik and S. Wszołek, Tarnów 1996, pp. 13-27. Heller M., Nowa fizyka i nowa teologia, Tarnów 1992.

Heller M., Ostateczne wyjaśnienia wszechświata, Kraków 2008.

Heller M., Pabjan T., Stworzenie i początek Wszechświata. Teologia - filozofia - kosmologia, Kraków 2013.

Heller M., Usprawiedliwienie wszechświata, Kraków 1984.

Heller M., Wszechświat jest tylko drogą, Kraków 2012.

Hetherington N., Cosmology, religious and philosophical aspects, [in:] Encyclopedia of science and religion, ed. J. W. von Huyssteen, New York 2003, pp. 177-183.

John Paul II, Letter to the Reverend George V. Coyne, S.J., Director of the Vatican Observatory, Vatican 1 June 1988.

Kant I., Rozprawa filozoficzna o religii i moralności, trans. K. C. Mrongowiusz, Toruń 2006.

Kragh H., The origin of the modern anthropic principle, "Journal of Cosmology" 13 (2011), pp. 3700-3705.

Lucia U., Entropy generation approach to cell systems, "Physica A" 406 (2014), pp. 1-11.

Macek W. M., Teologia nauki, [in:] Oblicza racjonalności. Wokót myśli Michała Hellera, ed. B. Brożek et al., Kraków 2011, pp. 203-237. 
Martínez-Berumen H. A., López-Torres G. C., Romo-Rojas L., Developing a method to evaluate entropy in organizational systems, "Procedia Computer Science" 28 (2014), pp. 389-397.

Mezei B. M., Demythologizing Christian philosophy: an outline, "Logos i Ethos" 2013 no. 2 (35), pp. 109-146.

Newman J. H., The Idea of a University, London 1907.

Oldroyd D. R., Theories of the earth and its age before Darwin, [in:] History of science and religion in western tradition: an encyclopedia, ed. G. B. Ferngren, New York-London 2000, pp. 446-452.

Pius XII, Le prove della esistenza di Dio alla luce della scienza naturale moderna, "Acta Apostolice Sedis" 44 (1952), pp. 31-43.

Polkinghorne J. C., One World. The Interaction of Science and Theology, PhiladelphiaLondon 2007.

Roush S., Copernicus, Kant, and the anthropic cosmological principles, "Studies in History and Philosophy of Modern Physics" 34 (2003) no. 1, pp. 5-35.

Simmons E., God of the gaps, [in:] Encyclopedia of science and religion, ed. J. W. von Huyssteen, New York 2003, pp. 382-384.

Skoczny W., Dziedzictwo fizykoteologii we współczesnej myśli chrześcijańskiej, "Zagadnienia Filozoficzne w Nauce" 13 (1991), pp. 79-85.

Smolin L., The life of the cosmos, Oxford 1997.

Smoot III G. F., Cosmic Microwave Background Radiation Anisotropies: Their Discovery and Utilization, , "Review of Modern Physics" 79 (2007), pp. 1349-1379.

Thomas Aquinas, On Being and Essence, [in:] idem, Selected Writings, ed. \& transl. R. McInerny, London 1998, p. 30-49.

Thomas Aquinas, On the Eternity of the World, [in:] idem, Selected Writings, ed. \& transl. R. McInerny, London 1998, pp. 711-717.

St. Thomas Aquinas, The "Summa Theologica", trans. Fathers of the English Dominican Province, vol. 1, London 1920.

Wetterich C., Quantum mechanics from classical statistics, "Annals of Physics" 325 (2010), pp. 852-898. 